\title{
14. The feasibility of universal basic income
}

\author{
Olli Kangas
}

\section{INTRODUCTION}

The Finnish government's experiment with universal basic income attracted exceptionally broad public interest both within Finland and around the world. Although universal basic income had been widely discussed in academic, popular, and policy circles for decades, Finland was the first country to give universal basic income a nationwide, controlled, randomised trial. Much of the feedback surrounding this pilot project has been positive (Chapter 13) and has lauded the Finnish government for bravely attempting to develop a new model of social security. However, reactions have not all been positive, and opponents of universal basic income have used the shortcomings of the Finnish experiment to argue against the efficacy of the basic income or related policies. Thus, proponents of universal basic income fear that the Finnish experiment weakened the political appeal of the scheme and diminished perceptions of its political feasibility. These fears are exacerbated by the fact that the results of the experiment are often taken out of context, simplified and misrepresented by policymakers and mass media seeking sensational news (Widerquist, 2018: 3).

The Finnish experiment merged universal basic income with the existing system of social security benefits in Finland. In order to properly define the functional division of labour between universal basic income and existing income transfer schemes - and because of the obligatory nature of the experiment - Finland devised special legislation pertaining to the experiment (Chapters 3 and 4). For instance, because Finland is a member state of the European Union (EU), it must adhere to the subsidiary principles of the EU. Although these principles hold that social policies are, in principle, the responsibility of national governments, in practice, the implementation of universal basic income in an EU member state brings national policy into conversation with EU-level agreements on the free movement of labour, labour legislation, and other aspects of coordination between member states. Indeed, the relation- 
ship between national universal basic income policy and EU-level legislation was considered when the research group began to plan the basic income experiment and to write the first report (Kangas and Pulkka, 2016; Chapter 3; see also Kalliomaa-Puha et al., 2017).

Thus, the Finnish experiment brings up questions regarding the possibility of implementing basic income in a single EU member state and the various EU-level constraints which would affect the implementation of such a policy (see Van Parijs and Vanderborght, 2017). Given that the Finnish experiment is central to many discussions regarding the feasibility of universal basic income, and the experiment's status as the only nationwide attempt to institute the income on a trial basis, this chapter discusses whether the experiment increased the feasibility of universal basic income in Finland. To assess the feasibility, we employ the often-used typology of the political feasibility of universal basic income provided by De Wispelaere and Noguera (2012; see also Torry, 2016). This typology suggests that the feasibility of the unconditional income transfer scheme depends on four factors - namely, strategic, institutional, psychological and behavioural factors. With help from this typology and evaluations of the Finnish experiment presented both in this volume and in earlier publications (for example, Kangas et al., 2019, 2020), we examine whether the experiment makes universal basic income seem like a viable option for future social policy in Finland.

This chapter proceeds in the following way. First, we briefly introduce the concept of political feasibility. Then, we introduce the four factors of political feasibility outlined above and discuss them in relation to the planning (Kangas and Pulkka, 2016) and evaluation (Kangas et al., 2019, 2020; Hämäläinen et al., 2020) of the Finnish experiment with universal basic income. Finally, we summarise our discussion and argue that the experiment's findings make it highly unlikely that universal basic income will be implemented in Finland in the near future.

\section{POLITICAL FEASIBILITY}

A policy is politically feasible "when the background conditions are such that there is a reasonable probability of the policy becoming actualised in the foreseeable future' (De Wispelaere and Noguera, 2012). In other words, policies are politically feasible when reform is preferred to the status quo. Furthermore, scholars have asserted that 'political feasibility refers to constraints arising from human will, opposed to natural, physical, and technological impediments' (De Wispelaere and Noguera, 2012). Thus, it depends on the actions and interactions of human beings.

Politics implies agency and power relations. Both need to be taken into account when assessing the political feasibility of a given policy. Following 
De Wispelaere, and Noguera (2012: 19), we distinguish between discrete and diffuse agency in this paper. Discrete agency belongs to readily identifiable actors that have specific, defined and distinctive interests, and the capacity to carry out reforms. Discrete agents are usually the most visible political agents (politicians, social elites, bureaucrats, and organisational actors such as trade unions). Diffuse agency is comprised of many kinds of actors and movements with little or no clear, strong, leadership or internal coherence (the general public, families with children, recipients of social assistance, etc.).

The distinction we make here is similar to Olson's (1965) distinction between privileged groups (usually small groups) with a concentrated interest and large groups with diffuse interests. Needless to say, both types of agents and agencies coexist and interact in different ways. We suggest that discrete and diffuse agents confront a different pair of the four factors affecting feasibility outlined above. Whereas discrete agents confront the strategic and institutional feasibility of universal basic income, diffuse agents confront its psychological and behavioural feasibility. Each of these four factors has important ramifications for our analysis, so we cover them all individually.

\section{STRATEGIC FEASIBILITY}

Strategic feasibility is linked to Weber's (1989 [1904-5]) and Geertz's (1973: 314) statement that policy ideas require strong and committed carriers to be feasible, even if they have a high level of public support. Before explaining further, it is useful to distinguish between cheap and expensive political support (De Wispelaere, 2015: 72-3). Whereas cheap support often vanishes in actual political struggles or when the presenter of an idea gains political power, expensive support demands strong commitment and participation from pressure groups to push an idea through to the realisation of a policy. In other words, cheap support is support which lacks 'either the commitment or the capacity to engage in the necessary political action to build a sustainable coalition around the policy' (De Wispelaere and Noguera, 2012: 22). We can see that universal basic income in Finland has cheap support insofar as studies have found that 60-70 percent of the Finnish public supports it in theory (for example, Andersson and Kangas, 2005; Airio et al., 2015; Chapter 11 in this volume) but only around 30 percent of the public supports universal basic income when confronted by the increases in tax rates that would accompany its implementation (Airio et al., 2016; Chrisp et al., 2020).

In Weber's (1989 [1904-5]: 90) famous analysis of the relationship between capitalism and Protestantism, he emphasised that ideas that have been effective in history have been supported by dominant or powerful social groups. Likewise, Geertz (1973: 314) wrote that ideas must be carried by powerful social groups in order to have powerful social effects. In other words, ideas 
must be institutionalised in order to be reified and actualised - they may not take hold or have an effect if they are not sufficiently revered, celebrated, defended, and imposed by a sufficiently powerful group of elites (discrete agents).

While there is a loose group of Finnish universal basic income enthusiasts representing diffuse interests, two small to medium-sized political parties in Finland, the Greens and the Left Alliance, provide discrete support for it. However, neither party can be classified as a powerful group because they do not possess the political power necessary to implement universal basic income. Finland's three largest political parties - the Social Democratic Party, the Finns Party, and the conservative National Coalition - are all against universal basic income. In a multi-party political system like Finland's, politicians must build coalitions between parties in order to successfully pass legislation and implement policy. One or two of those three bigger parties will be included in the subsequent coalition governments, which decreases the political feasibility of basic income.

Furthermore, social partners play crucial roles in the adoption and implementation of Finnish social policies. For instance, the Confederation of Finnish Industries and Finland's Central Trade Union Organisation have traditionally agreed upon a wide array of social policy questions relating to family leave, sick leave and pensions, during the course of centralised income policy negotiations (Alestalo et al., 1985). Both social partners (Chapter 2) and semi-private pension companies (Kangas, 2007) have demonstrated the value of social partners in Finnish policy by working together on pension policy. Due to their involvement in the political process, social partners 'own' these kinds of policy schemes and form an institutional barrier against political interference in those domains. Thus, for universal basic income or any other major social policy reform to pass, it must be supported by a robust coalition of political parties and social partners.

\section{INSTITUTIONAL FEASIBILITY}

Institutional feasibility is closely related to strategic feasibility. It refers to the administrative challenges posed by the implementation of a policy. These challenges pertain to updated citizen registers, implementing new payment tools, and monitoring payment of benefits (De Wispelaere and Noguera, 2012: 24-7). Given the accuracy and coverage of the population, social security, income and all other registers, there are no major problems in carrying out big social policy reforms in Finland.

Institutionalists emphasise that agents do not act in a vacuum; instead, they are constrained by previous policy actions, established institutions, and stable, conventional ways of acting and thinking in a given political arena. 
Political power and agendas of yesterday remain impactful today, frozen in present-day institutions and cognitive paradigms. This situation both facilitates breakthroughs in some policy areas and rules out policy options or ideas in others (Mahoney and Thelen, 2010; Béland and Cox, 2011; Schmidt, 2010). For example, Finland's income-related unemployment protection system is fund-based, and its funds are mainly administrated by trade unions. Therefore, this formal institution might hinder the implementation of universal basic income (see Chapter 2). The same goes for Finland's employment-related pension scheme.

Current legislation can also constrain actors' choices and perception of viable policy options. As we described in Chapter 3, current legislation can pose a major hurdle to the successful implementation of universal basic income, largely because of the administrative and legislative challenges inherent in integrating the legislation with existing national and EU-level social security legislation and norms (see for example, Kangas and Pulkka, 2016, Kalliomaa-Puha et al., 2016; Tuovinen, 2017). Lawmakers confronted two distinct challenges at the national level. First, they had to ensure that universal basic income laws met constitutional and other legislative stipulations (Chapters 3 and 4; see also Scharpf, 2000; Van Parijs, 2000). Second, they had to define how other, existing social security benefits should be related to or integrated with universal basic income - i.e. which benefits should be replaced or reduced if the income were introduced, and if so, by what or by how much. In contrast, the EU-level challenges facing lawmakers revolved around whether universal basic income could fall under EU regulations regarding the coordination of social security systems (883/2004). In short, lawmakers pondered whether it was possible to implement a universal basic income scheme in only one EU member state considering the depth of EU-level coordination vis-à-vis national legislation (The European Parliament and the Council, 2004).

In addition, there is one element of institutional feasibility that is specific to Finland: the political role of municipalities. Finland contains over 300 municipalities, and each has its own political duties and purviews. These include the duty to organise social and health services and the right to collect taxes to finance the fulfilment of this duty. While planning the experiment, representatives of the municipalities expressed concern about universal basic income's possible impact on municipalities' tasks and budgets. In short, the municipalities were sceptical of the basic income at the time of the experiment (Vogt et al., 2017).

\section{PSYCHOLOGICAL FEASIBILITY}

Psychological feasibility refers to the general public's acceptance of a policy (in this case, universal basic income). General opinion surveys showed that 
Finns' support for universal basic income ranged between 20 percent and 80 percent, depending on the formulation of survey questions (Pulkka, 2018). General framing, such as, 'Is universal basic income a good idea?' garnered high and robust support for it. In 2015, as much as 69 percent of the Finns said that it is a good or very good idea (Airio et al., 2015). The 2020 survey (see Chapter 11) that used the same question displayed significantly lower support levels (60 percent).

Furthermore, when survey respondents are told that taxes would be increased to pay for universal basic income, support for it drops to around 30 percent (Chapter 11; Airio et al., 2016; Chrisp et al., 2020). When survey questions are too general, they might paint too optimistic a picture of the possibilities of and popular support for universal basic income. The inverse is true for survey questions which are too specific. Even though research shows that it is unlikely that a universal basic income programme could be financed with increases in income tax alone (Van Parijs and Vanderborght, 2017; Andrade et al., 2019; Standing, 2020), the focus on tax revenue as the primary means to fund such programmes has undoubtedly skewed the psychological feasibility of the income and made the public's genuine support for it difficult to measure.

Because votes for politicians in democratic societies depend on constituencies' support, public opinion matters when these politicians set their policy and reform agendas. However, the simple 'bottom-up' view that constituents' opinions are directly and genuinely mirrored in political decisions is too simple and naïve. Democracy entails negotiations and is deliberative (Elster, 1998). Political elites negotiate and deliberate using techniques and devices which can effectively reframe, reformulate and manipulate public opinion. Thus, we can understand idea or policy framing as tools that elites use to legitimise their policy choices to the public (Campbell, 2002).

As we saw in Chapter 3, framing is an essential part of the political struggle of interpretation in which linguistic concepts and symbols give conceptual meaning to an issue and steer political debate. Ideas and policies are strategically framed so as to create a basis for political decisions and help political actors legitimise their decisions to their constituents. Via framing, political actors may, for instance, socially construct the sense of a need for policy reform (Kangas et al., 2014). Of course, politicians are neither the only nor the most powerful actors in framing political realities or future ambitions. As we saw in Chapter 13, national and international media alike framed public perception of the Finnish experiment and the basic income more generally, and as shown by Widerquist (2018) media oftentimes tend to be sensational rather than objective and spin the results to favour this or that interpretation. 


\section{BEHAVIOURAL FEASIBILITY}

In order to be behaviourally feasible, a policy must neither fail to produce its desired outcomes nor produce counterproductive effects (De Wispelaere and Noguera, 2012: 29-32). Because the Finnish government undertook its experiment to determine whether basic income can effectively fortify incentives to seek paid work and combat disincentives, we should measure the behavioural feasibility of the experiment with reference to its effects on Finns' employment and incentive to work (Kangas et al., 2019, 2020). Evaluation of the experiment shows that universal basic income recipients did not work significantly more or less than the control population (Hämäläinen et al., 2020 and Chapter 6 in this volume). Thus, the experiment did not produce the desired outcome insofar as it did not increase or decrease Finns' employment.

This result opened the experiment itself up to vicious critiques, because its ability to enhance Finns' employment became the defining criteria of evaluation for many observers. However, evaluations of the experiment have demonstrated that it had many other effects. For instance, reception of universal basic income was positively and significantly associated with improvements in Finns' mental and social well-being (Chapter 7). Universal basic income recipients reported less financial and mental stress than their control counterparts (Chapter 8), and reported that they felt more confident, felt that they had more control over their lives, and felt that they were more trusting of other people and societal institutions (Chapter 10). Thus, when assessing the behavioural feasibility of universal basic income, researchers should attempt to weigh its recipients' quality of life alongside the large-scale economic effects of it.

\section{CONCLUSION}

This chapter asked whether Finland's pilot project with universal basic income increased the political feasibility of implementing universal basic income in Finland in the future by assessing its strategic, institutional, psychological, and behavioural feasibility. We will address each of these in turn, here, and then make more general comments regarding the pilot project's effects on the perceived feasibility of universal basic income in the future.

Regarding strategic feasibility, we found that universal basic income advocates do not form a discrete group powerful enough to impose their idea onto their peers. Instead, they form a diffuse group and lack the political power and organisation to translate their advocacy into powerful social action. Regarding institutional feasibility, we identified several rigid constraints which limit the implementation of universal basic income in Finland: the Finnish social security system (in which social partners have a strong influence on the admin- 
istration of the main social insurance programmes), the ways in which political power and will are frozen in formal institutions, and the difficulty of coordinating national and EU-level policy with regard to universal basic income.

Here, we suggest that although modest basic income benefits could be carried out at the national level, true universal basic income would be difficult to enact in the EU - unless residents in a country which enacted universal basic income are willing to finance benefits that can be exported from the country to some other EU country or outside the EU. Regarding the psychological feasibility of the basic income, we found that popular support for it depends in part on how we measure it and that the relatively cheap popular support that it enjoys is not strong enough to make significant changes to the prevailing discourse surrounding social policy. Finally, regarding its behavioural feasibility, we found that the experiment did not necessarily have its intended effect on Finns' employment - or at least not significantly enough. However, we also suggested, in line with other studies (for example, Van Parijs, 1995; Standing, 2020; Bregman, 2017; Van Parijs and Vanderborght, 2017), that universal basic income may improve recipients' feelings of freedom, dignity and self-determination. This suggests both that basic income bears a huge burden of proof regarding its behavioural feasibility and that some analysts misplace this burden by emphasising only its potential employment, rather than any of its possible human, impacts.

Thus, there are serious obstacles in the political feasibility of basic income in Finland. Usually, exceptional times open up new possibilities. However, the COVID-19 pandemic has not increased or intensified political discussions on the implementation of basic income in Finland as it has done in many other countries. The main reason is that the welfare state's stress test caused by the pandemic has shown that the existing welfare state has worked very well under exceptional circumstances and it has cushioned the effects of the pandemic rather well. Only a very few temporary measures have been introduced to protect vulnerable groups (for example, Kangas \& Kalliomaa-Puha, 2021). Institutional continuity rather than significant changes in the policy paradigm prevails. To sum up our analysis on the feasibility of basic income in Finland, we can conclude that for the time being universal basic income is not a realistic policy option. However, never say never.

\section{REFERENCES}

Act on The Basic Income Experiment (1528/2016; available in Finnish at https://finlex .fi/fi/laki/alkup/2016/20161528) (accessed 14 December 2020).

Airio, I., Kangas, O., Koskenvuo, K. and Laatu, M. (2015) 'Kansa kannattaa perustuloa' ['People support basic income'], available at http://tutkimusblogi.kela.fi/ arkisto/2759 (accessed 19 December 2020). 
Airio, I., Kangas, O., Koskenvuo, K. and Laatu, M. (2016), 'Tasaveroon pohjautuvaan perustuloon suhtaudutaan varauksellisesti' ['Scepticism about basic income that is based on flat-rate taxes'], available at http://tutkimusblogi.kela.fi/arkisto/2942 (accessed 19 December 2020).

Alestalo, M., Flora, P. and Uusitalo, H. (1985), 'Structure and politics in the making of the welfare state: Finland in comparative perspective', in Alapuro, R., Alestalo, M., Haavio-Mannila, E. and Väyrynen, R. (eds), Small States in Comparative Perspective, Oslo: Norwegian University Press, pp. 188-210.

Andersson, J. O. and Kangas, O. (2005), 'Universalism in the age of workfare: Attitudes to basic income in Sweden and Finland', in Kildal, N. and Kuhnle, S. (eds), Normative Foundations of the Welfare State: The Nordic Experience, London: Routledge, pp. 112-29.

Andrade, J., Crocker, G. and Lansley, S. (2019), 'Alternative funding methods', in Torry, M. (ed.), The Palgrave International Handbook of Basic Income, Cham: Palgrave Macmillan, pp. 175-90.

Béland, D. and Cox. R. H. (eds) (2011), Ideas and Politics in Social Science Research, New York: Oxford University Press.

Bregman, R. (2017), Utopia for Realists and How We Can Get There, London: Bloomsbury.

Campbell, J. L. (2002), 'Ideas, politics, and public policy', Annual Review of Sociology, 28, 21-38.

Chrisp, J., Pulkka, V-V. and Rincón García, L. (2020), 'Snowballing or wilting? What affects public support for varying models of basic income?', Journal of International and Comparative Social Policy, 36(3), 223-36.

De Wispelaere, J. (2015), An Income of One's Own? The Political Analysis of Universal Basic Income, Tampere: Tampere University Press.

De Wispelaere, J. and Noguera J.A. (2012), 'On the political feasibility of universal basic income: an analytical framework', in Caputo, R. (ed.), Basic Income Guarantee and Politics, New York: Palgrave Macmillan, pp. 17-38.

Elster, J. (ed.) (1998), Deliberative Democracy, Cambridge: Cambridge University Press.

Geertz, C. (1973), The Interpretation of Cultures, New York: Basic Books.

Hämäläinen, K., Kanninen, O., Simanainen, M. and Verho, J. (2020), Perustulokokeilun arvioinnin loppuraportti: Rekisterianalyysi työmarkkinavaikutuksista [The Final Evaluation Report on the Basic Income Experiment: Register-based Analysis on Labour Market Effects], Helsinki: VATT Institute for Economic Research, VATT muistiot 59.

Kalliomaa-Puha, L., Tuovinen, A-K. and Kangas, O. (2016), 'The basic income experiment in Finland', Journal of Social Security Law, 23(2), 75-88.

Kangas, O. (2007), 'Finland: labour markets against politics', in Immergut, E. M., Anderson, K. M. and Schoulze, I. (eds), The Handbook of Western European Pension Politics, Oxford: Oxford University Press, pp. 248-96.

Kangas, O., Jauhiainen, S., Simanainen, M. and Ylikännö, M. (eds) (2019), Perustulokokeilun työllisyys- ja hyvinvointivaikutukset: Alustavia tuloksia Suomen perustulokokeilusta 2017-2018 [The Basic Income Experiment 2017-2018 in Finland: Preliminary Results], Sosiaali- ja terveysministeriö, Raportteja ja muistioita 2019:19].

Kangas, O., Jauhiainen, S., Simanainen, M. and Ylikännö, M. (eds.) (2020), Suomen perustulokokeilun arviointi [Evaluation of the Finnish Basic Income Experiment], Sosiaali- ja terveysministeriö, Raportteja ja muistioita 2020:15. 
Kangas, O. and Kalliomaa-Puha, L. (2021), 'ESPN Thematic Report: COVID-19 impact on social protection and social inclusion policies: Finland', Brussels: European Commission.

Kangas, O., Niemelä, M. and Varjonen, S. (2014), 'When and why do ideas matter? The influence of framing on opinion formation and policy change', European Political Science Review, 6(1), 73-92.

Kangas, O. and Pulkka, V-V. (eds) (2016), Ideasta kokeiluun? Esiselvitys perustulokokeilun toteuttamisvaihtoehdoista [From an Idea to an Experiment-Preliminary Report on Alternatives for Basic Income Experiment], Helsinki: Valtioneuvosto, Valtioneuvoston selvitys ja tutkimustoiminnan julkaisusarja 13/2016.

Mahoney, J. and Thelen, K. (eds.) (2010), Explaining Institutional Change: Ambiguity, Agency, and Power, New York: Cambridge University Press.

Olson, M. (1965), The Logic of Collective Action: Public Goods and the Theory of Groups, Harvard: Harvard University Press.

Pulkka, V.-V. (2018), 'Finland shares unconditional money, but the public view remains polarized', available at http://blogs.bath.ac.uk/iprblog/2018/01/23/finland -shares-unconditional-money-but-the-public-view-remains-polarised (accessed 20 December 2020).

Scharpf, F. (2000), 'Basic income and social Europe', in Van der Veen, R. and Groot, L. (eds), Basic Income on the Agenda, Amsterdam: Amsterdam University Press, pp. 155-60.

Schmidt. V. A. (2010), 'Taking ideas and discourse seriously: explaining change through discursive institutionalism as the fourth new institutionalism', European Political Science Review, 2(1), 1-25.

Standing, G. (2020), Battling Eight Giants. Basic Income Now, London: Tauris.

The European Parliament and the Council (2004), Regulation (EC) No 883/2004 on the Coordination of Social Security Systems, Brussels: The European Parliament and the Council.

Torry, M. (2016), The Feasibility of Citizen's Income, New York: Palgrave Macmillan.

Tuovinen, A.-K. (2017), Perustuslainmukainen perustulokokeilu [Evaluation of the Basic Income Experiment in the Light of the Finnish Constitution], Helsinki: Kela, Working Papers 114.

Van Parijs, P. (1995), Real Freedom for All: What (If Anything) Can Justify Capitalism? Oxford: Oxford University Press.

Van Parijs, P. (2000), 'Basic income at the heart of social Europe: Reply to Fritz Scharpf', in Van der Veen, R. and Groot, L. (eds), Basic Income on the Agenda, Amsterdam: Amsterdam University Press, pp. 161-9.

Van Parijs, P. and Vanderborght, Y. (2017), Basic Income. A Radical Proposal for a Free Society and a Sane Economy, Cambridge, MA, and London: Harvard University Press.

Vogt, E., Porko, M., Hakola, J., Uotinen, S., Tyni, T., Lehtonen, S., Punakallio, M. and Lindberg, E. (2017), Kunnat ja perustulo [Municipalities and Basic Income], Helsinki: Kuntaliitto.

Weber, M. (1989 [1904-5]), The Protestant Ethic and the Spirit of Capitalism, London: Allen \& Unwin.

Widerquist, K. (2018), A Critical Analysis of Basic Income Experiments for Researchers, Policymakers, and Citizens, Cham: Palgrave Macmillan. 